\title{
Information Technology in Navigation: Problems in Legal Implementation and Liability
}

\author{
Michael Tsimplis ${ }^{1}$ and Spiros Papadas ${ }^{2}$ \\ ${ }^{1}$ (School of Law, City University of Hong Kong) \\ ${ }^{2}$ (Institute of Maritime Law, University of Southampton, UK) \\ (E-mail: M.Tsimplis@gmail.com)
}

\begin{abstract}
E-navigation poses significant challenges for shipping. The analysis of the legal norms in the International Regulations for Preventing Collisions at Sea (COLREGS) and court decisions supports the use of information technology on the bridge for the purpose of improving navigational safety. However, the current regulatory and standardisation requirements hamper the introduction of new information streams in navigational systems and remove the incentives for investment in navigation technology. The liability arising from navigational failures will remain on the employer of the crew irrespective of how the additional navigational information is provided to the navigational systems. The shipowner's liability may depend on the way information streams are provided to the ship only within the context of the Civil Liability Convention (CLC) 1992 and other similar pollution conventions where the characterisation of the navigational system as a navigational aid or an aid to navigation may decide the issue of liability. Research on the legal background of these terms underlines the need for a clear distinction between the two terms to be made. An interpretation is proposed which ensures that the CLC liability exception operates in accordance with the underlying legal requirements.
\end{abstract}

\author{
KE Y W ORD S \\ $\begin{array}{lll}\text { 1. e-Navigation. 2. COLREGS. 3. Shipping. } & \text { 2. }\end{array}$
}

Submitted: 19 March 2018. Accepted: 6 December 2018. First published online: 21 January 2019.

1. INTRODUCTION. Information technology provides opportunities for the development of additional and alternative methods of performing navigational tasks. The increasing ship-to-shore connectivity provides the option of integrating routeing, ship performance and operational aspects for each voyage and port visit. The use of information provided by ports and authorities, as well as the knowledge of intended routes and destinations of other ships navigating in the same area, can help the navigator predict and avoid encounters creating collision risks. Calvert (1969) argues, with respect to the use of radar, 
that collisions will only be reduced if uncertainty is reduced. The primary uncertainty is the reaction of other ships. Information technology, used as a means of communication, can reduce the uncertainty about the future movements of other ships and, because of this, it is distinct from the addition of technology providing simply situational awareness.

Despite this important difference, the experience gained from the introduction of radar, of satellite navigation systems, of Electronic Chart Display Information Systems (ECDIS), and of the Automatic Identification System (AIS) is a source of scepticism and reluctance to introduce information technology onto bridges. Problems have been identified with respect to human factors (Fuchs, 1958), incorrect plotting (Healy, 1964) and overreliance on technology (Volk, 1957). The scepticism is summarised well by the International Maritime Organization's (IMO's) statement that: “if current technological advances continue without proper co-ordination there is a risk that the future development of marine navigation systems will be hampered through a lack of standardization on board and ashore, incompatibility between vessels and an increased and unnecessary level of complexity" (IMO, 2009).

e-Navigation is defined within the IMO Strategy for the development and implementation of e-Navigation (IMO, 2009) as: "the harmonized collection, integration, exchange, presentation and analysis of marine information on board and ashore by electronic means to enhance berth to berth navigation and related services for safety and security at sea and protection of the marine environment. e-navigation is intended to meet present and future user needs through harmonization of marine navigation systems and supporting shore services."

e-Navigation data, in raw formats, are too complex for direct human use. Thus, the data has to be interpreted and delivered in an understandable format, which would preferably be standardised in order to avoid training navigators for each different instrument. This is of course correct as a general approach. However, ships are not currently compatible, and are fitted with a wide range of different manufacturers' equipment. Complexity of information does not necessarily lead to more complex ways of navigating and, as the primary objective is safer and more efficient navigation, an increased level of complexity may well be justified.

In our view, the reluctance is better understood as part of the business model of the shipping industry. Each ship represents a large investment in a volatile market and any additional upgrades or improvements may risk rendering the investment unproductive.

The call for co-ordination and standardisation has two significant consequences. First, it delays the introduction of information technology on the ship's bridge. The IMO regulatory mechanisms, developed for the introduction of minimum standards for all ships, is thus used in a way that hinders the quick development of better, safer and more efficient ships. The second consequence is that any competitive advantage for companies that wish to invest in such technologies is removed, because they cannot reap the benefits of innovation. It is submitted that for information technology, where improvements can be rapid, standardisation is not the way forward, as the optimal way for the use of such information is yet unknown.

In addition to the scepticism, which arises from perceptions created by accidents linked with the introduction of technology in the past, there are important regulatory and liability issues worrying the owners and operators of ships that need to be clarified. This paper considers, for the first time, two interconnected legal issues. The first concerns the regulatory path that needs to be followed for new information streams to be introduced on the bridge. 
The second issue concerns the liability associated with their use and the link of this liability to the way the data is provided to the ship.

2. THE REGULATORY CHALLENGE OF e-NAVIGATION. Safety of navigation has significantly improved with time as a result of better situational awareness obtained through the use of new instrumentation, better training for navigators, safety management approaches, traffic separation schemes and shore control centres. Additional navigational information, can, if properly utilised, further improve the situational awareness of the navigator.

Information to the ship can be provided through various pathways. Here we deal with two scenarios, each concerned with one exclusive information provider. In the first scenario the provision of information is undertaken by national or international authorities. This scenario corresponds to a sea traffic control system putting the burden for accurate and useful information on a traffic control centre and leaving to the master the task of decision-making, without much consideration of the quality of information provided. The other scenario involves the voluntary sharing of information between ship operators and navigators. The first scenario will face the problem of differential capabilities coastal States have in setting up and maintaining such a system. It will also pass on the cost of its development and maintenance to taxpayers. The second scenario avoids the two aforementioned problems, but involves a risk of having un-standardised, and therefore, mixed-quality information.

Whichever way the information is provided to the ship, it must be displayed either on an existing console on the bridge, or on a separate dedicated display. The International Convention for the Safety of Life at Sea (SOLAS) Regulation V/19 (United Nations (UN), 1974) provides a list of shipborne navigational systems and equipment ${ }^{1}$ that ships should carry and specifies the function each system and piece of equipment must serve. In addition, there is the possibility of using "other means" to perform the required function but such means must be approved by the national administration (SOLAS Regulation $\mathrm{V} / 19(3)$ ). All systems "shall be so installed, tested and maintained as to minimize malfunction" (SOLAS Regulation V/19(4)). Every new information system must be compliant with these requirements which are normally embedded in the far more detailed requirements of the International Electrotechnical Commission (IEC) and the International Organization for Standardization (ISO). However, if the new information (for example, real-time meteorological data) is overlaid on an existing screen, which is part of standardised equipment, for example ECDIS, the additional functionality is likely to render the equipment nonstandardised and non-approved. This would then require further testing of the equipment to confirm two things: first that the new data stream does not affect the performance of the already standardised functions of the equipment and second, that a failure of one of the functions will not result in the loss or malfunction of the other functions. ${ }^{2}$ In addition,

\footnotetext{
1 "Equipment" is not defined under SOLAS. United Nations Convention on Law of the Sea (UNCLOS) Article 21(2) restrains the coastal state from regulating the "design, construction, manning or equipment of foreign ships unless they are giving effect to generally accepted international rules or standards." UNCLOS Article 94 of UNCLOS imposes flag state responsibility on the High Seas (UN, 1982).

2 Standards for ECDIS require: "Nor should the connection of optional equipment degrade the performance of ECDIS below this standard” (IMO, 2006). For Automatic Radar Plotting Aids (ARPA) see (IMO, 1995). SOLAS Regulation V-19 (6) provides for segregation: Integrated Bridge Systems shall be so arranged that failure of one sub-system [...] does not cause failure to any other sub-system (UN, 1974).
} 
training of the navigator on the new functionality would be required. ${ }^{3}$ Failure to go through such a process could provide the basis of intervention by port authorities and could lead to demands of using solely standardised equipment with a possibility to detain the ship. Currently, during certification, any additional functionality introduced by manufacturers is inspected to ensure that it does not interfere with the official requirements, although this does not prevent accidents arising from incorrect settings of such functionality.

The alternative option, that of displaying data onto a new dedicated console, is not illegal because SOLAS does not prescribe an exclusive list of equipment that should be available on the bridge. It does however require that the new console does not usurp any of the functions of the system or equipment prescribed by V-19 or be deemed to be an AISby-other-means exchanging data with shore-based facilities pursuant to Regulation V-19 2.4.5.4 (UN, 1974). At the same time, such an option does not make the usage of the new console unregulated. On the contrary, the duty of the shipowner to ensure safety in the navigation and the management of the ship may expose the shipowner, who moves first into e-Navigation, to accusations of unsafe practices. A coastal State could prohibit the use of such equipment, if it is operated without approval by the flag administration, until it becomes consistent with internationally agreed Construction, Design, Equipment and Manning (CDEM) requirements, as required by Article 21 (2) of the 1982 UN Convention on the Law of the Sea (UNCLOS) (UN, 1982; De Bievre, 1985), in other words, until it becomes standardised.

Both methods of displaying additional electronic information promote standardised solutions over competition for continuously improving products and efficiency. This slow prescriptive regulatory regime, a characteristic of shipping and the IMO, removes the competitive aspect of investment in technological development within the shipping industry. It follows that, if information technology developments in shipping are to be encouraged, it is essential to establish a less prescriptive and more performance-based approach for new systems, which would facilitate the quick adoption of information technology and encourage service providers and shipowners to invest in it.

3. TRAINING REQUIREMENTS FOR e-NAVIGATION. One argument against the introduction of new data streams on the bridge suggests that the additional information would confuse navigators and distract them from the use of traditional means, thus increasing accidents. This makes it necessary to look at the role of training and at the rules on safety of navigation.

Formal training of seafarers is based on the requirements of the 1978 International Convention on Standards of Training, Certification and Watchkeeping for Seafarers (STCW) (UN, 1978). Compliance with the STCW requirements is essential for a ship to be permitted to trade in foreign ports. Failure to comply with the STCW provisions may lead to the detention of the ship. The STCW is implemented by flag states all around the world.

\footnotetext{
3 See Adamopoulos (2018), Raising the alarm on ECDIS - a misleading title. The Marine Accident Investigation Board (MAIB) reports, cited in support of these concerns are exclusively related to human errors in the usage of the system (CFL Performer (MAIB, 2008), CSL Thames (MAIB, 2012), Ovit (MAIB, 2014), Commodore Clipper (MAIB, 2015), Muros (MAIB, 2017)); there were serious issues with the use of ECDIS. The audible alarm was inoperative due to user settings (CSL Thames, Ovit, Commodore Clipper, Muros), the crew was either untrained (CFL Performer) or incompetent in its use (CSL Thames, Ovit), while in some, the safety warnings were off (CFL Performer, Ovit, Commodore Clipper, Muros).
} 
The standards of competence for masters under the STCW Code include position determination by "using modern electronic navigational aids, with specific knowledge of their operating principles, limitations, sources of error, detection of misrepresentation of information and methods of correction to obtain accurate position fixing" (UN, 1978. Table A-II/2 Col.2). STCW includes obligatory training so that the seafarer can detect malfunctions or wrong input of data (UN, 1978. Section B-I/12 para 8(2) and 40). The ECDIS training programme requires competency of the trainee in identifying the risks of using electronic information. The risks suggested are the potential errors in displayed data, especially when combined with the over-reliance on new technology and a failure to keep a good look-out (UN, 1978. Section B-I/12 para 41 and 49). Similar requirements are in place for AIS, with the United Kingdom Maritime and Coastguard Agency (MCA) adding that mariners are advised to initiate action to correct improper installation (MCA, 2006). Cross-checking of the information available rather than blind reliance on it is also required. For example, in Selat Arjuna and Contship Success (1998) the court allocated the blame for the collision to the vessel that used the system for "wrongly interpreting the information from (or which ought by proper operation of the ARPA (Automatic Radar Plotting Aid) to be available) on radar". Overall, the existing training requirements support the use of electronic navigational aids within a framework which includes their operational principles, vulnerabilities and errors. These principles would equally apply to any additional functionality.

It has been argued that the use of additional information could increase the navigational risks primarily through overreliance and reduced vigilance. Aviation pilots examine more than 40 instruments, while navigating at speeds 20 times faster than a ship. Aviation is characterised by a small number of manufacturers leading to a high level of cockpit layout standardisation, which in turn makes the training of pilots easier. By contrast, shipping is characterised by significant differences in bridge layout and, as a consequence, requires more formal training of a generic nature. As a result, type-specific training is carried out only to a limited extent. This suggests that aviation may not be a good example to compare with shipping. In our view, and despite the significant differences in the level of standardisation, the comparison demonstrates that any additional risks created do not arise from the limitations of the human capability to assimilate information, but from issues pertaining to training and watchkeeping as well as to vigilance.

4. SAFETY OF NAVIGATION AND NAVIGATIONAL INFORMATION. The arguments against the use of information technology become weaker, when considered within the context of the International Regulations for Preventing Collisions at Sea (COLREGS) (UN, 1972). The duty of good seamanship is the primary precaution against collision risks and COLREGS provide the general standard for discharging this duty by prescribing, to the extent possible, the appropriate behaviour of ships at sea. COLREGS (Rule 2) accept that the departure from a rule is permissible, where adherence to the rules would result in a collision, and a violation of a rule would avoid it (Gault et al., 2016).

Maintaining a proper look-out (Rule 5) and safe speed (Rule 6) are important navigational duties that need to be discharged by all ships under all conditions of visibility. Both require improved situational awareness, which must be optimised, according to extensive case law, with whatever information and means available. In Hal Antillen N.V. v. Mount Ymitos (1999) the Court held that "[the vessel] should have kept a better look-out both 
visually and with the highly sophisticated equipment onboard." Therefore, if information technology can provide improved situational awareness and it is available, then it should be used by navigators. The duty of good seamanship demands it.

The Western Neptune and St Louis Express (2010) is a case law example demonstrating this principle, and it concerns the collision between the Western Neptune, a seismic survey ship towing an array of streamers, and the container ship St Louis Express. The navigational aids available on the container ship included an Automatic Identification System (AIS) interfaced with the main radar and the ECDIS. The AIS signal, transmitted from the survey ship, included information on (a) the length of the towed arrays; (b) other ships involved with the survey and (c) the difficulty in the manoeuvring of the survey ship. However, the officer of the watch on the container ship did not use the display option that would have made the AIS additional information visible and, as a result, ignored the exclusion zone and contributed to the collision damage. The survey ship was found also to be at fault, because, among other things, it did not communicate via Very High Frequency (VHF) International Maritime Mobile (IMM) radio with the container ship, when it was realised that the route change undertaken by the container ship was likely to cause a collision with the towed array. Both identified faults convey the same message from different perspectives: any information system that can assist in avoiding a collision should be used properly and fully. Similarly, English courts consistently underline that the VHF cannot be used to agree non-compliance with the COLREGS between two ships. A statement indicative of this position can be found in Aleksandr Marinesko and Quint Star (1998), where the judge stated that "It cannot be too strongly emphasised that vessels should be navigated in accordance with the Collision Regulations and not by agreement on the VHF".

The same conclusion can be drawn with respect to the requirement for safe speed. Having more information on what other ships do, or plan to do, more information on weather, currents, underwater obstructions, bathymetry, etc, will improve situational awareness and enable navigators to adjust the ship's speed to correspond to safe navigation.

The knowledge of the intentions of the other ship's navigation are particularly resisted, because allegedly they create navigational risks. However, they are arguably no different from the indicators on cars on the road. Calvert (1969) demonstrated the point that the issue of safety of navigation concerns, in essence, the reduction of uncertainty regarding the future moves of ships. Therefore, in our view, the only viable objections to having additional information on a ship's bridge concern the reliability of that information and the potential of human error by overreliance on it.

The first objection is, from the point of view of good seamanship, dealt with under COLREGS Rule 7 (UN, 1972), which requires that "assumptions shall not be made on the basis of scanty information", a good example of which is Oden and Pulkovo, (1989) ${ }^{4}$. It is further clear that good seamanship requires obtaining the best situational awareness and this task inherently includes cross-checking of instruments with awareness by sight and hearing. The second objection, that the availability of additional information might make navigators look less out of the window (compare with MAIB (2017)) and focus more on the navigational equipment screens, ${ }^{5}$ thus reducing their situational awareness (Brooks

\footnotetext{
4 The IMO guidelines for the use of AIS note that additional sources of information do not replace but instead support the existing systems. (IMO, 2015). The court in Western Neptune and St Louis Express (2010) cited these guidelines at paragraphs 46-49, while pointing out problems that could arise if AIS was used on its own.

5 Looking out of the window, although normally an essential requirement, does not necessarily lead to better situational awareness where the design of the bridge windows is deficient. See the MAIB (2017) report on the
} 
et al., 2016), has less to do with e-Navigation and more with training of seafarers and task allocation on the bridge. Perhaps a wealth of additional information may require an additional dedicated bridge officer in order to ensure that the safety advantages materialise. If increased navigational safety can be achieved only in this way, then the applicable norm suggests that such a solution should be adopted. Shipowners would raise a counter argument about the financial costs. It is, however, arguable that taking bureaucratic tasks away from the bridge officers and performing them ashore could create the necessary financial room to support the increases in safety. As regards the alleged risks concerning the transitional period, despite being real, they cannot be sufficient to delay the use of information for safer and more efficient navigation.

5. THE EFFECT OF e-NAVIGATION ON A SHIPOWNER'S LIABILITY. It has been demonstrated that the use of information technology in a way which increases navigational safety is dictated by the applicable navigational norms. The next step is to identify which of the two scenarios on the way the information can be provided to a ship is legally preferable. Providing the information to the ship may require reallocation of tasks and more resources on the bridge but will preserve independence in navigational decision-making. The development of sea traffic centres, which process information and give options or instructions to the ship's navigator, would be a cheaper option for shipowners to start with, but would reduce the freedom of navigational decisions. However, neither of the options will lead to the navigational responsibility being taken away from the ship's master. In both cases, the collision avoidance rules will apply as they do today, and the obligations of the ship's master will remain unaltered. The correctness of this position is supported by several English cases, one example being the grounding of the True North which grounded while being navigated by an auto-helm unit and an Electronic Chart System (ECS) receiving position information from a Global Positioning System (GPS) receiver. There was a discrepancy of about $300 \mathrm{~m}$ between the true position of the ship and that which was plotted on the ECS (Australian Transport Safety Bureau, 2004). The master, suffering from fatigue, did not adequately cross-check the GPS positions on the ECS by other navigational means "nor did he maintain an adequate visual or radar check to ensure the ship remained in safe water". The lack of situational awareness and the overreliance on the GPS were both held to have contributed to the accident. Cases such as the True North are at the heart of the concerns put forward by various bodies in relation to new systems. The declining number of accidents (Porathe et al., 2014) indicate that appropriate management of available information, including the intentions of other ships, can reduce collision risk and the number of close-quarters situations.

6. AIDS TO NAVIGATION AND NAVIGATIONAL AIDS. While the liability of the shipowner for damages is not affected by the additional information or the way it is provided and displayed on a ship, there is one situation where these factors are relevant. This concerns an exception of the shipowner's strict liability established under many pollution liability regimes. The operation of this exception depends on whether the additional information system falls in the category of "navigational aids" or under the category of "aids

collision between pure the car carrier City of Rotterdam and Roll-On-Roll-Off (RO-RO) freight ferry Primula Seaways where the off-axis bridge windows and lack of visual references led to the pilot's disorientation. 
to navigation". These terms appear in international conventions, judicial judgments and academic writings, but their use, as it will be shown below, is inconsistent.

Under UNCLOS (UN, 1982) the term "navigational aids" is used to denote devices external to the ship. ${ }^{6}$ STCW stipulates that a seafarer must demonstrate the "Ability to operate safely and determine the ship's position by use of all navigational aids and equipment commonly fitted on board the ships concerned" (UN, 1978. Table A-II/3 Col.2). This suggests that at least some, if not all, navigational aids are on board ${ }^{7}$ a contrast with the use of the term under UNCLOS. The IMO sub-Committee on the Safety of Navigation has characterised ECDIS, AIS, and gyro-compasses as "navigational aids" (IMO, 2002). However, under SOLAS Regulation V/19 they are "shipboard navigational systems and equipment".

"Aids to navigation" are, under SOLAS Regulation V/13 (UN, 1974), the responsibility of the Contracting Governments indicating that they are external to the operation of the ship. STCW requires that seafarers should have: "Ability to determine the ship's position by use of: aids to navigation, including lighthouses, beacons and buoys" (UN, 1978. Table AII/1). This statement suggests either that aids to navigation are always external to the ship, because of the reference to lighthouses, beacons and buoys or that they can be both on board and external to the ship. Finally, the Convention on Limitation of Liability for Maritime Claims 1996 (LLMC) provides for limitation of liability for "claims in respect of ... loss or damage to property (including damage to harbour works, basins and waterways and aids to navigation), occurring on board or in direct connection with the operation of the ship ... and consequential loss resulting therefrom" (UN, 1976. Art. 2(1)(a)). The natural interpretation of the term suggests that aids to navigation are external to the ship because they are grouped together in a context, quoted in the parenthesis above, with harbour works, basins and waterways.

An effort to overcome this confusion has been undertaken by the International Association of Marine Aids to Navigation and Lighthouse Authorities (IALA), which has provided definitions of what is a "navigational aid" and what an "aid to navigation". The distinction is based on the location of the device assisting navigation. "Navigational aids" are on board while "aids to navigation" are not (IALA, 2018). Many mariners and engineers actually use the term "Aid to Navigation" or "AtoN" when they refer to a buoy or lighthouse, things which can be effectively charted, while they consider the on board equipment as navigational aids. Despite this practical support of IALA's definition, this distinction cannot be applied to pre-existing international conventions and therefore the confusion cannot be resolved in this way.

There is no case law directly considering the distinction between the two terms. English case law $^{8}$ in its majority uses the term "navigational aid" to refer to on board devices that

\footnotetext{
6 Within the UNCLOS (UN, 1982) "navigational aid" is referred to at Article 21(1)(b), which provides that coastal states may adopt laws and regulations relating to the innocent passage for "the protection of navigational aids and facilities and other facilities or installations". Also, Art. 43(a) requires user states and states bordering on a strait to collaborate "in the establishment and maintenance in a strait of necessary navigational and safety aids or other improvements in aid of international navigation". This terminology refers to devices external to the ship in both cases.

7 The amendments introduced in the STCW by the implementation of the Polar Code (IMO, 2014) require additionally that the seafarer must "understand and identify hazards associated with limited terrestrial navigational aids in Polar Regions" (IMO, 2016). This provision clearly concerns "navigational aids" situated on land, as the word "terrestrial" is used. Such stipulations can be found in FAO, ILO, IMO (1999).

${ }^{8}$ From Ocean Victory (2014. p.64), "She was equipped with the usual navigational aids, including gyro compass, two radars and two GPS".From Hill Harmony (1998. p.374), "the vessel was properly equipped with
} 
assist navigation. This is consistent with IALA's definition. However, there is a statement in one English case where "aid to navigation" refers to an on board device. In particular, the judgment of the Miguel De Larrinaga (1956) case includes the following statement: "It has been said more than once that radar, like any other of these scientific instruments with which modern ships are supplied, is an aid to navigation, and is to be treated as such." This is an obiter statement and it is clear that the judge was not considering the distinction between the two terms. Thus, English case law supports the IALA distinction, in its majority with one exception that can be distinguished as being given at a time when the need for differentiation had not been developed or because the statement is clearly not focused on making such a differentiation. However, as there is no decision distinguishing between the two terms, it is also arguable that under English law the terms are equivalent.

Publications also use the two terms inconsistently. There are papers on the development of a minimum luminous range for major lighthouses (Fuad et al., 2017), the application of navigational aids and aids to navigation in the Malacca and Singapore straits (Guy and Kruse, 1999) and the integration of navigational technologies, (Lam and Leyzack, 2007), where the IALA definitions are used. However, other studies show larger or smaller inconsistencies (Towey, 1986; Raymos, 1986; Letulle, 1966). The ambiguity in the use of the terms is also reflected in national instruments, with the very recent example of the UK Port Marine Safety Code, using both terms interchangeably to refer to external devices (MCA, 2016).

7. THE EXCEPTION TO A SHIPOWNER'S POLLUTION LIABILITY. The characterisation of information systems used in navigation would not matter much, were it not for the consequence of the characterisation within the context of pollution liability regimes. This exception of the shipowner's liability originally appeared in the International Convention on Civil Liability for Oil Pollution Damage (CLC) (UN, 1969) but has been copied verbatim in several other liability conventions. These include the 2007 Nairobi Wreck Removal Convention (UN, 2007. Article 10(1)(c)), the 2001 Convention on Bunker Oil Pollution Damage (UN, 2001. Article 3(3)(c)), and the Hazardous and Noxious Substances (HNS) Convention (UN, 1996. Article 7(2)(c)).

The CLC establishes strict liability for the registered shipowner of a tanker carrying persistent oil in bulk as cargo. The otherwise strict liability of the shipowner is, however, excluded under Article III (2)(c) of the CLC (UN, 1969), if the pollution incident took place due to a failure of the authority responsible for the "maintenance of lights or other navigational aids in the exercise of that function." The reading of the provision suggests the term is referring only to failure in the maintenance of, external to the ship, navigational assistance. However, there is case law suggesting otherwise.

The Tsesis (1983), a Swedish Supreme court decision, concerned a ship's grounding that led to oil pollution covered by the CLC. The Tsesis decision has been repeatedly characterised as a controversial case (Gauci, 1997; Tiberg, 1984; Gunasekera, 2011). The shipowner raised a defence against the imposed strict liability by arguing that the incident

appropriate charts and other navigational aids for the voyage”. From Western Neptune and St Louis Express (2010), "Her navigational aids include: (i) A gyrocompass on the bridge and a further gyro compass in the seismic instrument and control room on B deck. (ii) Three radars with ARPA, all interfaced with the gyro and speed log. (iii) An electronic chart display and information system (ECDIS). (iv) An automatic identification system (AIS) which was also interfaced with the main radar and with ECDIS". 
was attributable to the failure of Sweden to update the charts of the area where the accident took place. The court examined whether this failure fell under Article III (2)(c) (UN, 1969) thus exempting the shipowner's liability. The Swedish Supreme Court held that the exception to the shipowner's liability under CLC Article III (2)(c) was applicable, because the maintenance of navigational aids included hydrographical surveying for the purpose of producing new charts. This aspect of the judgment was highly debated, as three judges dissented as to the character of charts as a "navigational aid". (Tiberg, 1984). The court tried to interpret the provision by considering which navigational aids can be subject to "maintenance", and whether charts fell under this category. It has been suggested that if the fault alleged is a failure to establish or improve navigational aids, this is distinct from a failure to maintain them.

Tiberg (1984) argues that the interpretation of the exclusion in the way adopted by the court transfers the liability for pollution damage away from the shipowner and this exposes other parties to liabilities. With respect, we do not find this argument persuasive, because the International Oil Pollution Compensation (IOPC) Fund covers such pollution liability, where the shipowner is not liable under the exception. Thus, the claimant's recovery is not jeopardised. Tiberg (1984) further suggests that the intention was to penalise governments, where they were negligent in maintaining the external navigational aids as a part of their obligation to provide for the safety of navigation. Tiberg (1984) and, earlier, Abecassis (1978) make the point that, if a government has failed to place a light on a particular hazard, such failure is outside the scope of the exception; whereas if it had placed it and it failed due to no maintenance, a ship can claim exemption. However, it can be counterargued that the intention was to penalise shipowners, where they have been contributorily liable, and not where the pollution damage occurred solely because of the failure of a government. In addition to the Tsesis decision there have been other unsuccessful attempts by shipowners to escape liability by use of the same exception by suggesting deficiencies in pilotage services (Jose Marti incident, IOPC (1987)) and even deficiencies in the system providing information on the depth of a dredged channel (the Nissos Amorgos incident, IOPC (1997)).

The Tsesis decision suggests that navigational aids within the CLC context may or may not be on board the ship, an interpretation which contrasts both with the UNCLOS and the IALA definitions. It is submitted that the focus of the definition should be on the method of provision of information instead of on the location of the device that assists navigation. For the operation of the CLC Article III.2(c) (UN, 1969) exception the question must, in our view, be whether the cause of the pollution damage was exclusively a failure of maintenance by a government. Whether it concerns charts, beacons or electronic signals, to the extent that these were deficient and the exclusive cause of the pollution damage, the shipowner was intended, under the CLC, to be free of liability. ${ }^{9}$ This functional approach would also apply to other existing instruments and information streams on board the ship and could potentially significantly extend the scope of the exclusion in the CLC and the other aforementioned pollution liability conventions.

\footnotetext{
9 This effect is to be achieved through the exception under CLC Article III.2(c) (UN, 1969) or through the recourse preserved under Art. III.5 but, we argue here, it serves better the spirit of the 1992 CLC if it operates through Art. III.2(c). In such a case it will also exclude liability for pollution damage following such fault of any government whether contracting or not to the CLC.
} 
8. STATUTORY INTERPRETATION OF "AIDS TO NAVIGATION". The terms in international conventions must, according to Article 31 of the 1969 Vienna Convention on the Law of Treaties (UN, 1969), be interpreted "in accordance with the ordinary meaning of the words and in the light of its object and purpose. .. A special meaning shall be given to a term if it is established that the parties so intended." There is very little in the negotiating texts of the aforementioned international conventions to conclude on the ordinary meaning of the two terms in question. Under English law the ordinary meaning of the word, that is, its proper and most known signification must first be identified (Bennion et al., 2017. Section 22.1). In doing so the courts may look at the way the term is used by people, or how it is defined officially. In Manchester City Council v Romano (2004) the court used the definition of the term "health" developed by the World Health Organisation to interpret an English Act including this term. The court may also be obliged to rely on non-legal expertise (Bennion et al., 2017. Section 22.1). For technical and scientific terms, the corresponding technical meaning should be used, (Holt and Co v Collyer, 1881) unless a different intention is evidenced. There are of course several other rules for a process which is often complicated and depends on the specific aspects of each case. However, the consideration of the three rules mentioned above permits a number of points to be made. One can assume that the two terms under discussion ordinarily have one and the same meaning which could be limited depending on their contextual usage. The first rule of the ordinary meaning would point towards accepting such an approach. However, to the extent that the World Health Organisation's definition for the term "health" can be used in interpreting the term health in an English Act, it is at least equally arguable that the definitions developed by IALA can also be used to interpret the term "Aids to Navigation"- note that "Health" and "Aids to Navigation" appear in the titles of the corresponding intergovernmental organisations. Thus, the development of definitions by IALA may well affect the adopted interpretation of the terms by the English courts. Furthermore, to the extent that this is a technical term, it is likely that expert opinion will be called in. Many mariners and engineers use the term AtoN or use capitals "Aid to Navigation" when they refer to a buoy, lighthouse, AIS AtoN, etc. while radar, "normal" AIS, depth sounders, compasses, GNSS receivers, ECDIS, paper charts, vessel navigation lights, etc are all navigational aids. This differentiation supports an argument that a distinction has been developing and is becoming progressively more established in the minds and views of technical organisations and technical experts. We have used above the English law rules for statutory interpretation. Under these rules, the interpretation of these terms can be considered unclear, but a differentiation between the two terms has been developing and this is supported by the definition by IALA and the usage by technical experts. It is to be expected that other legal systems may adopt different approaches and lead to a different conclusion. This is an additional reason why some sort of clarification is needed.

There is also the question of whether the ordinary meaning of a term should reflect the ordinary meaning at the time the treaty was originally agreed or whether an evolutionary approach should be adopted. In the case of this group of liability conventions agreed over a span of 30 or more years an evolutionary approach is the only approach that makes sense.

Taking into account the "object and purpose" of the conventions can also assist in identifying the correct interpretation of the term. It is very clear that all of the pollution conventions aim to enable recovery for pollution damage by victims, through the establishment of a system based on strict and limited liability which is insured compulsorily and is 
supported by direct action against the insurer. The party strictly liable is protected by exceptions, two of which operate only in the absence of any causative negligence by that party. Furthermore, the recourse rights of the party strictly liable are preserved in all conventions and therefore where, as in the Tsesis (1983) decision there is a fault by a third party, whether governmental authority or not, recourse action is available, even if the registered shipowner, in the case of the CLC, is obliged to pay first. It is worth noting that, as a matter of fact, public authorities and the coastal states are the major claimants in most pollution incidents. Therefore, the question is whether the intention of the pollution conventions was that the shipowner would have to pay the claimant state authorities, even where the only failure was by the state itself, or whether the shipowner in that case would exclude his liability. It is arguably fairer that the shipowner escapes liability altogether in such a case. However, there could be other, non-state claimants, who, if the exception works in the suggested way, would then have to move from the certainty of compensation provided by the CLC to a claim against the state for breach of its statutory duties or in negligence. Restricting the question within English law, such claims are not easy to win (see Harding, 1989). In one reported Scottish case, Anchor Line (Henderson Brothers) Ltd v. Dundee Harbour Trustees (1922), the lack of action by the harbour authorities to force pilots, through disciplinary action, to wait for ships in the designated location led to a ship passing that location without a pilot, and colliding with an unmarked wreck. This was an exceptional case and normally it is very difficult to establish liability in negligence for authorities. It is also very difficult to establish a right to damages arising from a breach of statutory duty by an authority. Therefore, the concern that third parties may remain without compensation by the state responsible, if the shipowner's liability is exempted, is well founded.

However, the same difficulties will be faced by a shipowner, trying to recover under a recourse claim. Thus, the argument that the shipowner may rely upon a recourse claim against a state, is not in general correct. Note though that the IOPCF would in general provide compensation to a third party claiment in such a case.

9. INFORMATION CONTROL AND ITS LINK TO LIABILITY. The objective of the CLC is to establish strict liability for the shipowner. Thus, where the state's failure is only contributory to the pollution damage, liability will remain with the shipowner. However, where the pollution damage is exclusively due to a failure by the state and especially where the state is in effect the major claimant, it is neither fair nor practical to make the shipowner liable. This argument is not, however, capable of conclusively resolving the interpretation of the exception in question. It does, nevertheless, support the Tsesis (1983) decision. The policy outcome is also desirable: if a state fails in that specific task, it will not receive compensation and may also become liable to third parties. It would then have to become more vigilant in ensuring its navigational assistance is appropriate and up to standard. This, will make navigation safer, discharging also the state's international duties to this effect. Thus, it is submitted, that the Tsesis decision is correct and that it reflects a fair and appropriate way of approaching the limits of the shipowner's strict liability. It also provides us with a method for dealing with navigational information in general.

When navigational information is generated on board by direct observation, for example by a magnetic compass or a radar, then any malfunction should fall on the shipowner and such a failure cannot lead to the exception of his liability. However, with other systems, the answer is more complicated and depends on whose failure has caused the accident. Where, 
for example, the location of the ship, obtained through a Global Navigation Satellite System (GNSS), is transmitted from the ship to other ships under a compulsory requirement of AIS operation, the failure of the AIS transmission of one ship cannot be argued as being a failure of a system of the receiving ship. In such a case the liability under the CLC (UN, 1969) would not, however, be exempted, unless the failure of transmission is a failure by a government or authority in the maintenance of such a system. This requirement could perhaps be satisfied, where the AIS signals are redistributed by a sea traffic centre operated by an authority.

This interpretation would provide for the consistent interpretation of the CLC and will be applicable to new information streams and products assisting navigation, as all exceptions under Article III (2) (UN, 1969) concern situations beyond the control of the shipowner. Where the responsibility for the information lies with the shipowner or other non-governmental entities, then the shipowner would remain strictly liable. Where the information is produced and broadcast by public authorities, it should be considered as an "aid to navigation" irrespective of the presence of a receiver on board the ship, except, of course, where the failure is of the receiver. This definition is in line with the current developments in shipping and could also permit the adoption of the e-Navigation strategy, due to the fact that it focuses on information exchange, instead of on the location of the device, and provides the flexibility to distinguish between innovative systems concerning navigation.

The operation of information exchange systems does not rely only on the production of information, but also on its emission, reception, display and interpretation. The suggested arrangement requires a separation of duties and liability as follows. Shipowners have to ensure that the equipment and displays on board are properly functioning and that the crew is competent in interpreting and cross-checking the information streams. However, the shipowner's liability would be excluded for failures caused by deficiencies in the information streams or the quality of the information where the information is provided by a government or other responsible authority. In this way a clear-cut rule is created, which is not only compatible with current case law, but also with the development of new innovations, which cannot be confined in the internal/external dualism suggested by IALA.

Resolving the terminological confusion by focusing on the link with liability is against the adopted practical distinction, coded in the IALA definition, and would probably be resisted by operators and service providers who would not consider linking liability, which may differ between states, as a practical basis for categorising instrumentation. Engineers and operators may also prefer the IALA definition which is easier to implement and does not require an understanding of the operation of the information system.

However, the link with liability is only a side-product of the functional criterion we suggest. If information is generated by a ship or by other ships without interference or standardisation by authorities, then it would be a navigational aid. If the information is in one or another way provided through a public authority, this would lead to it being characterised as an aid to navigation. This definition in most cases leads to a categorisation similar to that made by IALA with respect to conventional objects and systems.

10. CONCLUSIONS. The legal duty for safe navigation demands the use of all means, standardised or not, in order to obtain optimum situational awareness. This includes navigational information of every kind.

The introduction of a single new stream of information onto a console projecting standardised information, which either exists on board (ECDIS), or is received and transmitted 
electronically (AIS), could render the system in need of further standardisation and testing. The current prescriptive standardisation approach hampers efforts to use information technology for navigational purposes quickly and efficiently. Developing self-regulatory requirements supervised by classification societies and enabled on the basis of exceptions granted by the flag state would significantly facilitate the development of new solutions, boost the investment on them and reward innovative shipowners and companies. Adding tasks to the workload of the ship's bridge may require additional manning or a reconsideration of the tasks undertaken to avoid risks arising from fatigue and vigilance decrement. The transfer of bureaucratic tasks to the shore, by transferring the required information, could allow navigators to focus on purely navigational aspects. Thus, a reconsideration of task allocation is an option which has to be considered.

The responsibility for collision situations will stay with the master and his employer. The only aspect in which the shipowner's liability may be affected concerns the liability for pollution damage, as established under international conventions. Within this context the characterisation of the system as "a navigational aid" or "aid to navigation", terms used inconsistently and confusingly by lawmakers, courts and academic writers alike, may be crucial. Clarifying the situation would require the modification of several conventions in order to be consistent with the IALA definition.

We propose that a definition based on the source of information, instead of the location of the hardware, would be a better approach to distinguish between "navigational aids", where the information is provided on board, and "aids to navigation", where the information is transmitted from outside the ship. There are important consequences that turn on this characterisation. First, the responsibility for the maintenance, standardisation and operation of each aid would be shared between the shipowner and the state. Second, the usage of electronic information on board would be facilitated for those streams that are transmitted by authorities, as the ships could rely more on them, compared to the information provided by private services or other users. With respect to the exception of shipowner's liability for pollution damage, the proposed division of responsibility will provide an equitable solution reflective of the general nature of the exceptions under Article III.2 of the CLC (UN, 1969). For systems where a mixture of information from state and private sources is used, the liability issue would depend, under our suggestion, on which stream of information has failed and why. Such instruments would be characterised as aids to navigation, as there is a contribution from a source outside the ship.

The current lack of definitions and lack of clarity in the wording of liability conventions hampers not only the coordination and standardisation of equipment by manufacturers, but also affects the operational standardisation of navigational behaviour. A more flexible way, adopting clear performance-based criteria for new information streams and services, will enable shipping navigational optimisation to evolve faster. This, coupled with a functional understanding of the terms "navigational aids" and "aids to navigation" would clearly link operational responsibility, maintenance and training with subsequent liability.

In an age where autonomous and remotely controlled ships are starting to become a realistic prospect, providing incentives for existing ships to use the available fast evolving technology more efficiently is crucial. The current regulatory environment discourages and slows down innovation, ${ }^{10}$ thus creating an unnecessary polarisation (conventional

10 This is true for all innovative designs in shipping, as demonstrated for example in Eurocontainer Shipping Plc v The Minister for the Marine (1992), which regarded the introduction of an innovative open-top/ hatchless container ship design. 
vs autonomous), in what should be a smooth transition to smart ships with increased information availability and automation.

\section{ACKNOWLEDGMENTS}

We are grateful to the reviewers of this paper for some challenging and stimulating comments. We also thank Dr. Johanna Hjalmarsson and Tomasz Krzynski for commenting on various drafts of this paper. The work has been undertaken as part of the Sea Traffic Management Validation Project co-funded by EU (Connecting Europe Facility/Motorways of the Sea) (Agreement No INEA/CEF/TRAN/M2014/1034312).

\section{REFERENCES}

Abecassis, D. (1978). Law and Practice relating to Oil pollution from ships. London: Butterworth \& Co Publishers Ltd.

Adamopoulos, A. (2018). Raising the alarm on ECDIS. Lloyd's List 26February 2018.

Aleksandr Marinesko and Quint Star. (1998). Lloyds Law Reports Vol. 1 (Queen's Bench), p.265. at p.278

Anchor Line (Henderson Brothers) Ltd v. Dundee Harbour Trustees. (1922). Lloyds Law Reports Vol. 10 (House of Lords), p.47.

Australian Transport Safety Bureau. (2004). Marine Safety Investigation No. 205: Independent investigation into the grounding of the passenger vessel True North. [online] ATSB. Available at: http://www.atsb.gov.au/media/25072/mair205_001.pdf [Accessed 06 Nov. 2018].

Bennion, F., Bailey, D., Norbury, L., Feldman, D. and Jones, O. (2017). Bennion on statutory interpretation. 7th Ed. LexisNexis.

Brooks, B., Coltman, T. and Yang, M. (2016). Technological Innovation in the Maritime Industry: The Case of Remote Pilotage and Enhanced Navigational Assistance. The Journal of Navigation, 69(4), 777-793.

Calvert, E. (1969). Human Factors and the Collision Problem. Journal of Navigation, 22(1), 48-56.

De Bièvre, A. (1985). Vessel Traffic Services and the Law. Journal of Navigation, 38(3), 347-364.

Eurocontainer Shipping PLC v Minister for the Marine. (1992). Irish Approved Judgments, 1990 No 295 JR, (Transcript), Lexis Citation 4873.

FAO, ILO, IMO. (1999). Report of the Joint FAO/ILO/IMO Working Group on Fishermen's Training MSC 71/INF.3 15. Food and Agriculture Organization, International Labour Organization, International Maritime Organization, p.41.

Fuad, A., Osnin, N., Fadzil, M. and Ahmad, M. (2017). Proposed Minimum Luminous Range for Existing Lighthouses in This Age of Global Navigation Satellite Systems by Using the Correlation between Light Intensity and Luminous Range. International Journal of e-Navigation and Maritime Economy, 6, 29-36.

Fuchs, J. E. (1958). Radar and Good Seamanship, JAG Journal, (3), 3-6.

Gauci, G. (1997). Oil pollution at sea. Chichester, England: Wiley.

Gault, S., Hazelwood, S. and Tettenborn, A. (2016). The law of Collisions at sea. 14th ed. London: Sweet and Maxwell, Thomson Reuters. para. 5-113.

Gunasekera, D. (2011). Civil Liability for Bunker Oil Pollution Damage. Frankfurt: Peter Lang GmbH, Internationaler Verlag der Wissenschaften.

Guy, N. and Kruuse, T. (1999). Application of New Generation Navigational Aids and Aids to Navigation in the Malacca and Singapore Straits. Singapore Journal of International and Comparative Law, 3, 337-339.

Hal Antillen N.V. v. Mount Ymitos MS. (1999). Federal Report Vol.147. 3rd District p.447, (5th Circuit. 1998)

Harding, A. (1989). Public duties and public law. Oxford: Clarendon, 229-274.

Healy, N. (1964). Radar Decision Re-Examined. JAG Journal, 18, 223.

Hill Harmony. (1998). Lloyds Law Reports Vol. 2 (Queen's Bench), p.367. at p.374.

Holt \& Co v Collyer. (1881). Chancery Division, 16, p.718. at p.720.

IALA. (2018). International Association of Marine Aids to Navigation and Lighthouse Authorities Navguide, Aids to Navigation Manual, 8th ed.

IMO. (1995). Resolution A.283: Performance Standards for Automatic Radar Plotting Aids (ARPA). para. 3.9.1.

IMO. (2002). Report to the Maritime Safety Committee, NAV48/19. p.49.

IMO. (2006). Resolution MSC.232(82): Adoption of the revised performance standards for Electronic Chart Display and Information Systems (ECDIS). p.11 para. 15.11. 
IMO. (2009). International Maritime Organisation, Strategy for the development and implementation of eNavigation, MSC 85/26/Add.1, Annex 20.

IMO. (2014). International Code for Ships Operating in Polar Waters (Polar Code) MEPC 68/21/Add.1. IMO [online] http://www.imo.org/en/MediaCentre/HotTopics/polar/Documents/POLAR\%20CODE\%20TEXT\%20 AS\%20ADOPTED.pdf, p.3.

IMO. (2015). International Maritime Organisation, Revised Guidelines For The Onboard Operational Use of Shipborne Automatic Identification Systems (AIS). IMO, pp.11-12.

IMO. (2016). Consideration and adoption of amendments to mandatory instruments MSC/97/3/2 MSC/97/3/2. p.3. at Column 2 of Table A-V/4-2

International Oil Pollution Compensation Fund (IOPC). (1987). Annual Report. pp.16-17.

International Oil Pollution Compensation Fund (IOPC). (1997) Annual Report. pp. 106-111. see also: 71 FUND/EXC. 54/INF.3 and 71 FUND/EXC. 54/10

Lam, S. and Leyzack, A. (2007). Integrating GIS, ECDIS, and Web-based Marine Information System for Maritime Navigation and Coastal Protection. In: FIG Working Week 2007. Strategic Integration of Surveying Services, 6.

Letulle, R. (1966). Electronic Aids to Navigation and Their Basis as Fault in Marine Casualties. Villanova Law Review, 12, 160.

MAIB. (2017). Marine Accident Investigation Report (2017). Collision between pure car carrier City of Rotterdam and ro-ro freight ferry Primula Seaways. Report No 3/2017. [online] Marine Accident Investigation Branch, UK Department of Transport. Available at: https://assets.publishing.service.gov.uk/media/58984f60ed 915d06e1000025/MAIBInvReport3-2017.pdf [Accessed 06 Nov. 2018]

MAIB. (2017). Marine Accident Investigation Report (2017).Report on the investigation of the grounding of Muros. Report No. 22/2017. [online] Marine Accident Investigation Branch, UK Department of Transport. Available at: https://assets.publishing.service.gov.uk/media/59e601e7ed915d6aadcdaf18/MAIBInvReport 22_2017.pdf [Accessed 06 Nov. 2018]

MAIB. (2015). Marine Accident Investigation Report (2015).Report on the investigation of the grounding and flooding of the ro-ro ferry Commodore Clipper. Report No. 18/2015 [online] Marine Accident Investigation Branch, UK Department of Transport. Available at: https://assets.publishing.service.gov.uk/media/55c3108aed 915d534600000c/MAIBInvReport-18_2015.pdf [Accessed 06 Nov. 2018]

MAIB. (2014). Marine Accident Investigation Report (2014).Report on the investigation of the grounding of Ovit. Report No. 24/2014. [online] Marine Accident Investigation Branch, UK Department of Transport. Available at: https://assets.publishing.service.gov.uk/media/547c6f2640f0b60244000007/OvitReport.pdf [Accessed 06 Nov. 2018]

MAIB. (2012). Marine Accident Investigation Report (2012). Report on the grounding of CSL Thames. Report No. 2/2012. [online] Marine Accident Investigation Branch, UK Department of Transport. Available at: https://assets.publishing.service.gov.uk/media/547c6f8240f0b60244000021/CSLThames.pdf [Accessed 06 Nov. 2018]

MAIB. (2008). Marine Accident Investigation Report (2008). Report on the investigation of the grounding of CFL Performer. Report No 21/2008. [online] Marine Accident Investigation Branch, UK Department of Transport. Available at: https://assets.publishing.service.gov.uk/media/547c7001e5274a428d000063/CFLPerformer Report.pdf [Accessed 06 Nov. 2018]

Manchester City Council v Romano. (2004). All England Reports Vol. 4 (Court of Appeal), p.21. at para 69.

MCA. (2006). Maritime and Coastguard Agency, Radio: Operational Guidance on the Use of VHF Radio and Automatic Identification Systems (AIS) at Sea, MGN 324 (M+F) UK Department of Transport.

MCA. (2016). Maritime and Coastguard Agency, Port Marine Safety Code For all UK Harbour Authorities and other marine facilities, berths and terminals, UK Department of Transport.

Miguel De Larrinaga. (1956). Lloyds Law Reports Vol. 2 (Queen’s Bench), p.530.

Ocean Victory. (2014). Lloyds Law Reports Vol. 1 (Queen's Bench), p.59. at p. 64.

Oden and Pulkovo. (1989). Lloyds Law Reports Vol. 1 (Queen's Bench), p.280. at p.287

Porathe, T., Borup, O. and J. Jeong, (2014). Ship traffic management route exchange: acceptance in Korea and Sweden, a cross cultural study. In: Proceedings of the International Symposium Information on Ships. Hamburg: ISIS, 64-79.

Raymos, D. (1986). Liability on Government for improper placement of Aids to Navigation. Journal of Maritime Law and Commerce, 17(4), 517.

Selat Arjuna and Contship Success. (1998). Lloyds Law Reports Vol. 2 (Queen’s Bench ), p.489. at p.509. 
Tiberg, H. (1984). Oil Pollution of the Sea and the Swedish Tsesis decision. Lloyd's Maritime and Commercial Law Quarterly, 218.

Tsesis. (1983). Nytt Juridiskt Arkiv (N.J.A.) (Supreme Court), p.3.

Towey, T. (1986). Control and Financing of Navigational Aids in Ireland. International Journal of Estuarine and Coastal Law, 1, 184.

UN. (1969). International Convention on Civil Liability for Oil Pollution Damage 1969, (adopted 29 November 1969, entry into force 19 June 1975), 973 UNTS 3, as amended by Protocol of 1992 to amend the International Convention on Civil Liability for Oil Pollution Damage of 29 November 1969) (adopted: 27 November 1992, entry into force: 30 May 1996) 1956 UNTS 255.

UN. (1969). Vienna Convention on the Law of Treaties. United Nations (adopted: 23 May 1969, entry into force: 27 January 1980) 1155 UNTS 331.

UN. (1972). 1972 Convention on the International Regulations for Preventing Collisions at Sea (Colregs) (adopted: 20 October 1972, entry into force: 15 July 1977) 1050 UNTS 16.

UN. (1974). The International Convention for the Safety of Life at Sea 1974 (SOLAS) (adopted on 1 November 1974, entry into force 25 May 1980) 32 UST 47; 1184 UNTS 278.

UN. (1976). Convention on Limitation of Liability for Maritime Claims (1976 LLMC) and its Protocol of 1996 amending the Convention on Limitation of Liability for Maritime Claims of 19 November 1976 (1456 UNTS 221 (1996 LLMC) 35 ILM 1433 (1996), as amended by its 1996 and 2012 protocols.

UN. (1978). International Convention on Standards of Training, Certification and Watchkeeping for Seafarers, as Amended by the 2010 Manila Amendments to the Annex (STCW 78), (Adopted 7 July 1978, entered into Force:28 April 1984) 1361 UNTS 190.

UN. (1982). 1982 United Nations Convention on the Law of the Sea (UNCLOS), (adopted 10 December 1982, entry into force 16 November 1994) 1833 UNTS 3.

UN. (1996). International Convention on Liability and Compensation for Damage in Connection with the Carriage of Hazardous and Noxious Substances by Sea, (adopted 3 May 1996 superseded by Protocol of 2010 to amend the International Convention on Liability and Compensation for Damage in Connection with the Carriage of Hazardous and Noxious Substances by Sea, 1996, adopted 29 April 2010, not yet in force), IMO LEG-CONF.17/DC/1, 29 April 2010. The 1996 HNS Convention together with the 2010 Protocol form the 2010 HNS Convention. Not yet in force.

UN. (2001). 2001 International Convention on Civil Liability for Bunker Oil Pollution Damage (adopted 23 March 2001, entry into force on 21 November 2008), IMO Doc. LEG/CONF. 12/19, 23 March 2001.

UN. (2007). 2007 Nairobi International Convention on the Removal of Wrecks, (adopted 18 May 2007, entry into force 14 April 2015) 46 IML 697.

Volk, K. (1957). Some Legal Aspects of Collisions between Radar Equipped Ships. North Carolina Law Review, 36, 30.

Western Neptune and St Louis Express. (2010). Lloyds Law Reports Vol.1 (Queen's Bench), p.158. 